\title{
RAILWAYS AS A KEY PART OF INTEGRATED TRANSPORT SYSTEMS
}

\begin{abstract}
Integrated passenger transport system consists of many factors with various impacts on the entire system quality. In passenger transport, there are mostly individual passengers therefore it is difficult to determine all transport requirements. In the passenger transport system, there are several modes of transport, but passengers mostly use road and rail transport. Passenger transport system is influenced by many qualitative factors with various impacts. The paper is focused on analysis of the role of railways in integrated passenger transport systems. The analysis is from passenger point of view because the key element in railway passenger transport is the passenger (customer), who requires the transport from one place to another. A basic precondition for accomplishing the main requirement (transport), is making the complete offer which provides not only transport, but also other complementary services. There are several types of passenger trains, which jointly create a part of integrated transport system. Quality of this transport system depends on train route topology, timetable of trains, number and location of all stations and stops. Primary function of the transport system is providing transport for passengers on regional, national-interregional and international level; therefore, the analysis involves these levels.
\end{abstract}

Keywords: railway transport, passenger transportation, integrated transport, transport system

\author{
Martin Vojtek ${ }^{1}$ \\ ${ }^{1}$ Faculty of Operation and Economics of Transport and Communications, University of Zilina, \\ Univerzitná 1,01026 Zilina, Slovakia; +421 4151334 34; martin.vojtek@fpedas.uniza.sk \\ Martin Kendra ${ }^{2}$ \\ ${ }^{2}$ Faculty of Operation and Economics of Transport and Communications, University of Zilina, \\ Univerzitná 1, 01026 Zilina, Slovakia; +421 4151334 29; martin.kendra@fpedas.uniza.sk \\ Jaromír Širokýz \\ ${ }^{3}$ Faculty of Transport Engineering, University of Pardubice, Studentska 95, 53210 Pardubice, Czechia; \\ +420466036199; jaromir.siroky@upce.cz
}

\section{Introduction}

Passenger transport is generally considered as an activity, which arises as the consequence of spatial division of places, where people are in exact time and their need to move. Motivators for moving could be commuting - job or education, dealing with personal or working matters, travelling for vacation - hiking, sport, health, cultural and social facilities, visiting relatives and friends. Requirements for transport of passengers originate in the need to move, while the passenger transport is dependent on the willingness of travelling. Basic and general factor, which has got a significant impact to the transport of passengers, is demography. Specifically, the most relevant aspects are the progress of population quantity, economic and social indicators, standards of living, age structure, employment rate and disposable income. Regularity of transport is also key factor, which depends on structure of passengers and their reasons for travelling. Other specific factors are spatial accessibility of transport hub and price for transport. Influences on transport offer are geographical conditions, transport infrastructure, transport vehicles and environmental effects. Transport infrastructure factor consists of its structure, length, density, throughput, accessibility to residences and overall quality.

Passenger transport is divided into individual and public. Individual passenger transport includes walking, cycling and car transport. Public passenger transport includes railway, road, water, air, city and unconventional transport. From spatial point of view, passenger transport is divided into local, regional and long-haul, which is then divided into interregional transport - in one country or international transport - among two or more countries. From operational point of view, passenger transport is the sum of acts for providing mass transport of passengers which includes boarding, selling and checking the travel tickets, transfer of passengers' luggage, ensure all individual needs of passengers and organizing of other complementary services. From economical point of view, passenger transport is classified into tertiary sphere services. It means that there are not any material production values, but it is reflected in costs. In general, passenger transport has got a great social and political importance. Legislative fundamentals of organising and managing the passenger transport are constituted in higher legal standards and internal regulations of transport companies. (Kováč et al., 2011)

\section{Quality criteria of passenger transportation}

There are many associated criteria of passenger transportation such as safety, duration, price, reliability, comfort and complementary services. Safety is the dominant criterion and it is guaranteed normative by licences, permissions, certificates and verifications. Safety is measured by indicator of accidents per one billion passenger-kilometres. (Singhania et al., 2017)

Transport duration means the exact time of passenger moves from one place to another and it is closely related with speed. It does not mean the speed of the transport vehicle, there are other periods, such as time 
to go from home to the station, time to buy the travel ticket, boarding time, transport time, time to get off the train and time to reach the destination point. In case, where the traveller combines the trains, time for waiting to another train is also counted. Partial indicators are:

Getting off the vehicle time,

Going on stairs time,

Transport on escalators time,

Transport in elevators time,

Transport on walkways time,

- Buying travel ticket time. (Kendra, 2014)

Transport price is the criterion, which is dependent mostly on economic indicators. In market economy, there are three factors, which create the magical triangle costs, demand and competition. These factors are dependent on each other and they are also influenced by national economy, political situation and demography. Internal costs of the transport company are influenced by strategic objectives, economic situation and legislation. Transport demand reflects the range, how the transport company can affect the price for transport. Higher demand means opportunity to increase the price for transport, because travellers want to use the trains. Lower demand forces the transport company to decrease the transport price, because they must enhance the number of passengers in trains. Transport demand is highly influenced by macroeconomic indicators, such as GDP, employment rate and population economic activity rate. Another factor with significant impact is competition, which means other railway companies but also other means of transport, such as road, air or water transport. The transport company must deeply analyse and compare the price for transport with other transport companies, which offer the same or similar transport services.

Other factors with significant impact are reliability, offer of travel possibilities, vehicle occupation and coherence of transport system. Reliability is relative, because it depends on transport time and distance, while it proportionally decreases with mode of transport combination, for example train-bus. The most reliable are direct connections. Offer of travel possibilities has got a significant impact to quality of the whole transport system and structural modifications in passenger transport. It can be evaluated from spatial and temporal density. Spatial density means number of tariff point per some area, while temporal density means number of links per some time unit. Level of vehicle occupation compares real usage of the vehicle with maximum usage of vehicle.

Connectivity of passenger trains and other means of transport can be distinguished also from temporal and spatial point of view. Temporal connectivity is such sequence of arrivals and departures of different passenger trains and other means of transport, which allows changing the different passenger vehicles easily regarding necessary time. Spatial connectivity means the distance between two passenger vehicles, among which the passenger is moving. (Gasparik et al., 2016)

Travel comfort is also very important for passengers, especially nowadays. It consists of vehicle construction, interior hygiene, physiological and psychical influences.
Subjective feelings and experiences have also significant impact along with current mood of each passenger. Overall subjective feeling is the result of different conditions with different seriousness. Practically, there is a significant difference when the passenger travels to celebration or funeral. Qualification of these subjective feelings with some methods has not been successful yet.

Other complementary services with some impact to quality of traveling are services provided on board or in stationary facilities. For example, travel ticket office, info office, waiting room, toilets, wireless internet connection, post office, shop, restaurant, café and luggage storage are standard services provided in stationary facilities. On the other hand, there are services provided on board of the vehicle, for example luggage transport, bicycle transport, seat reservation, wireless internet connection, catering, electric socket, toilets, compartment for children, couchette, restaurant car, visual and acoustic information. Staff behaviour is also very important, because their function is not only checking the travel ticket, but also provide information about traveling and they must induce a good feeling among passengers. (Dedik et al., 2017)

Entire quality is defined as an ability to satisfy all requirements of customers. Specific signs for services in transport are insubstantiality, impossibility to store, inseparability, variability, complexity and uniqueness. Level of service quality can be perceived as a disharmony among expectation and perception. (Nedeliaková et al., 2013)

Customers - passengers have got different priorities which relate to quality of service. They usually remember low quality and high quality is a standard for them. The main challenge is to identify the passengers' needs and satisfy them in all cases, because every transport is realized in different conditions.

In central Europe, there is a modern trend of establishing integrated passenger transport systems in selected regions. Cores of these systems are terminals, where passengers can change vehicle and the mode of transport such as get off the bus and get on the train.

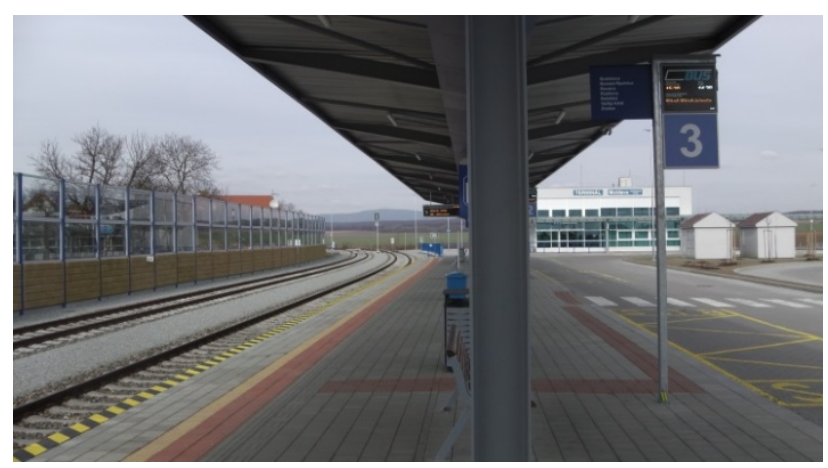

Fig. 1. Integrated passenger transport terminal in Moldava nad Bodvou mesto, Slovakia

These terminals are hubs, whence all routes and lines from some region or district are connected. Building these new terminals will improve transport accessibility in the selected region. Operators, who participate in the integrated passenger transport system, are more effective 
and notice increased demand for transport services. (Stoilova, 2018)

Basic element of the railway passenger transport system is railway passenger station, what is transport hub - a starting and finishing point for flows of passengers. Passengers can change the train type from long-haul train to regional train or contrariwise or simply enter or leave the system of railway transport. This is the reason, why it is multi-directional system, not one-way system, as the classic cross-docking system used in freight transport. Main functions of railway passenger stations are:

- $\quad$ ensuring safe, regular and fluent transport,

- ensuring technological services for operators,

- $\quad$ ensuring operation of facilities for traveling public (waiting room, ticket store etc.).

To sum up, it is necessary to accomplish preconditions to make railways efficient in integrated transport system:

- dominance of customer (passenger),

- timetable dependent on passengers' needs,

- $\quad$ synchronized arrivals and departures in all point in the transport system,

- harmonised conditions for all operators in the transport system,

- $\quad$ high reliability and punctuality.

There are some disadvantages of integrated transport system for railways:

- $\quad$ overcrowding of transport vehicle may occur,

- increased number of trains could reduce the throughput of railway,

- $\quad$ preference of busses (more flexible).

\section{Economic aspects of railway passenger transport}

Railway passenger transport must be evaluated from economical point of view. Basic evaluation method is operating costs calculation. Costs are financial representation of company sources consumption for realizing services per time. Internal costs of the transport company arise from operation of trains on railways. Thanks to calculation, the exact amount of these costs is known. In railway passenger transport, the calculation unit is the service - transporting of passengers. It can be defined by quantity (number of trains, vehicles), time (staff working time, time of traveling) or other way (passenger-kilometres, train-kilometres). (Dolinayová et al., 2016)

In general, there are these costs: vehicle costs (vehicle price - amortization, repairs and maintenance, insurance, operational cleaning), railway infrastructure access, staff costs (wages of vehicle-drivers and stewards), traction energy consumption and other indirect costs (management, marketing, travel ticket selling system, information system etc.). Sum of all costs, which are converted to one typified train on the route, is the base for making the tariff charges.

Railway vehicle costs are calculated this way:

$$
r_{\text {trkm }}^{R V} \frac{D_{Y}+\Sigma R M_{Y}+O C_{Y}+I N S_{Y}}{\emptyset \text { annual vehicle kilometrage }}
$$

where: $\mathrm{r}^{\mathrm{RV}}$ trkm - railway vehicle costs rate for trainkilometre $\left[€ /\right.$ trkm]; $D_{Y}$ - depreciation of vehicle per year $[€] ; \Sigma R M_{Y}-$ entire costs for repairs and maintenance of vehicle per year $[€]$; $O C_{Y}$ - entire costs for operational cleaning of vehicle per year $[€]$; INS - entire costs for vehicle insurance per year $[€] ; \varnothing$ annual vehicle kilometrage - average kilometrage of railway vehicle per year $[\mathrm{km}]$.

$$
C_{R V}=\operatorname{strkm} \cdot r_{t r k m}^{R V} \cdot N R V_{t r}
$$

where: $C_{R V}$ - entire railway vehicle costs per route $[€]$; $\Sigma$ trkm - sum of train-kilometres per route; $\mathrm{r}^{\mathrm{RV}}$ trkm railway vehicle costs rate for train-kilometre [€/trkm]; $\mathrm{NRV}_{\text {tr }}$ - number of railway vehicles in the train on the route [vehicles].

Staff costs are calculated this way:

$$
r_{\text {emph }}^{S}=\frac{\text { price for } \text { working }+ \text { equipment }}{\Sigma \text { work time }}
$$

where: $\mathrm{r}_{\text {emph }}^{\mathrm{S}}$ - staff costs rate for employee-hour [€/emph]

price for working - all month company's costs for the employee [€]; equipment - month costs for equipment of employee $[€] ; \Sigma$ work time - entire month work time of employee [hours].

$$
C_{S}=t_{r} \cdot C R_{S} \cdot r_{e m p h}^{S}
$$

where: $C_{S}-$ staff costs per route $[€] ; t_{r}-$ train ride time [hours]; $\mathrm{CR}_{\mathrm{S}}$ - conversion ratio: train ride time $\rightarrow$ employee-hour; $r^{S}$ emph - staff costs rate for employeehour [€/emph]

Traction energy consumption costs are calculated this way:

$$
C_{T E C}=\frac{\Sigma g t k m \cdot m c_{T E} \cdot s_{T E}}{1000}
$$

where: $\mathrm{C}_{\mathrm{TEC}}$ - entire traction energy consumption costs per route $[€] ; \Sigma$ gtkm - gross-tons-kilometres per route; $\mathrm{mc}_{\mathrm{TE}}$ - measurable consumption of traction energy per thousand gross-tons-kilometres; $\mathrm{s}_{\mathrm{TE}}-$ traction energy rate [€]

From operating costs calculation, tariff rates can be appointed. The tariff reflects valuable relations among the operator and passengers. These rates must include internal goals of the operator (increasing profit, decreasing costs, market share etc.), social sphere (quality and offer of public transport, reducing regional gaps etc.) and environmental aspects. Current transport demand and complementary transport offer are also important part of setting tariff rates. Application of economic aspects is 
described in the case study of fictional Express train from Bratislava to Bardejov in Slovakia.

Table 1. Operating costs per one drive of fictional train.

\begin{tabular}{|l|c|c|}
\hline \multicolumn{3}{|c|}{ COSTS (€) } \\
\hline vehicle & 1051.76 & $26.61 \%$ \\
\hline infrastructure & 649.18 & $16.42 \%$ \\
\hline vehicle-driver & 190.88 & $4.83 \%$ \\
\hline stewards & 184.38 & $4.66 \%$ \\
\hline traction energy & 888.74 & $22.48 \%$ \\
\hline indirect & 988.31 & $25.00 \%$ \\
\hline sum & $\mathbf{3 9 5 3 . 2 4}$ & $100.00 \%$ \\
\hline converted to one seat & 12.35 & \\
\hline converted to one placekm & 0.023265 & \\
\hline
\end{tabular}

Comparison of costs and revenues are shown in table 4 . When the result $>0 \rightarrow$ operation of passenger trains is economically effective. On the other hand, when the result $\leq 0 \rightarrow$ operation of passenger trains is not economically effective therefore the transport company would find some way how to reduce costs or increase revenues. Some government subsidies are also one of possible ways how to make operation of passenger trains economically effective.

Table 2. Economic effectiveness of fictional train on the route.

\begin{tabular}{|l|c|c|}
\hline \multicolumn{3}{|c|}{ Route: BRATISLAVA - BARDEJOV } \\
\hline Sum of costs & 3953.24 & $€$ \\
\hline Converted to one seat & 12.35 & $€$ \\
\hline Sum of revenues & 5210.00 & $€$ with VAT \\
\hline minus VAT & 4168.00 & $€$ \\
\hline $\begin{array}{l}\text { Result } \\
\text { (revenues - costs) }\end{array}$ & $\mathbf{2 1 4 . 7 6}$ & $€$ \\
\hline
\end{tabular}

The case study indicates that it is economically effective to operate trains on this route according to proposed conditions, which are not specified above. It shows the way how to consider operation of trains on new routes. Transport companies must consider enormous number of factors and conditions, which are necessary for objective and accurate assessment of providing railway passenger transport services.

\section{Conclusions}

1. Railway passenger transport companies (operators), who participate in the integrated passenger transport system, are more effective and notice increased demand for transport services.

2. All quality criteria of passenger trains have got different impact to the integrated transport system. It is necessary to determine their accurate impact, because they are closely dependent on passengers' needs and requirements and every passenger has got individual opinion.

3. Compare individual passenger needs with defined quality standards. The difference would indicate the level of passengers' satisfaction with the service.
4. A great emphasis is put on connectivity with other types of trains to eliminate waiting time in stations or terminals, where passengers must change the vehicle. Elimination of needless waiting can be reached by higher number of trains, buses and other passenger vehicles, which are used in passenger transport system.

5. Economic aspects of train operation are important for transport companies. Basic step is to compare operating costs with revenues to determine the economic effectiveness of train operation.

\section{Acknowledgment}

The paper is supported by the VEGA Agency by the Project 1/0791/18 "The Assessment of Economic and Technological Aspects in the Provision of Competitive Public Transport Services in Integrated Transport Systems" that is solved at Faculty of Operation and Economics of Transport and Communication, University of Zilina.

\section{References}

Dedik, M., Gasparik, J. and Zahumenska, Z. 2017 Quality Assessment in the Logistics of Rail Passenger Transport In: MATEC Web of Conferences, Doi: 10.1051/matecconf $/ 201713400009$

Dolinayová, A. et al. 2016. Ekonomika železničnej dopravy /Economics of Railway Transport/. Žilina: EDIS vydavatel'stvo Žilinskej univerzity. ISBN 978-80-5541283-2

Gasparik, J., Luptak, V., Mesko, P. 2016. New Methodology for Assessing Transport Connections Depending on the Integrated Transport Network. In: Proceedings of the Third International Conference on Traffic and Transport Engineering (ICTTE), Pages: 388-392, Belgrade, Serbia, 2016

Kendra, M. 2014 Integration of individual car transport and public passenger transport in cities. In: OPTi Proceedings: 1st international conference on engineering and applied sciences optimization. p. 1582-1592. ISBN 978-960-99994-6-5.

Kováč, M. et al. 2011. Osobná preprava 1 /Passenger Transportation 1/. Žilina: EDIS - vydavatel'stvo Žilinskej university. ISBN 978-80-554-0344-1.

Nedeliaková, E. et al. 2013. Metódy hodnotenia kvality prepravných služieb /Methods for evaluation of transport services quality/. Žilina: EDIS - vydavatel'stvo Žilinskej univerzity. ISBN 978-80-554-0817-0.

Singhania, V. and Marinov, M. 2017. An Event-based Simulation Model for Analysing the Utilization Levels of a Railway Line in Urban Area. In: PROMETTraffic\&Transportation, 29(5), pp:521-528, Doi: $10.7307 /$ ptt.v29i5.2306

Stoilova, S. (2018) Study of Railway Passenger Transport in the European Union. In: TEHNICKI VJESNIK-TECHNICAL GAZETTE, 25(2), pp: 587-595, Doi: 10.17559/TV20160926152630. 